Article

\title{
Study of An Innovative Approach of Roof Presplitting for Gob-Side Entry Retaining in Longwall Coal Mining
}

\author{
Xingyu Zhang ${ }^{1,2,3}$, Liang Chen ${ }^{4,5}$, Yubing Gao ${ }^{1,2, *}$, Jinzhu Hu ${ }^{1,2, *}$, Jun Yang ${ }^{1,2}$ and \\ Manchao $\mathrm{He}^{1}$ \\ 1 State Key Laboratory for Geomechanics and Deep Underground Engineering, China University of Mining \& \\ Technology, Beijing 100083, China \\ 2 School of Mechanics and Civil Engineering, China University of Mining \& Technology, Beijing 100083, China \\ 3 Department of Civil, Environmental and Architectural Engineering, University of Colorado, \\ Boulder, CO 80309, USA \\ 4 State Key Laboratory for Geomechanics and Deep Underground Engineering, China University of Mining \& \\ Technology, Xuzhou 221116, China \\ 5 School of Mechanics and Civil Engineering, China University of Mining \& Technology, \\ Xuzhou 221116, China \\ * Correspondences: yubing.gao@yahoo.com (Y.G.); hujinzhu_cumtb@163.com (J.H.)
}

Received: 29 July 2019; Accepted: 21 August 2019; Published: 28 August 2019

check for updates

\begin{abstract}
Gob-side entry retaining (GER) is a hot issue with regard to saving resources and reducing the drivage ratio in longwall mining. This paper investigates an innovative approach of roof presplitting for gob-side entry retaining (RPGER). RPGER uses the directional cumulative blasting to split the roof in advance. The rock roof within the presplitting range caves in gob after mining. The caved gangue can become the natural rib of the gob-side entry and expands to be the natural supporting body for resisting the upper roof movement. A numerical model of RPGER was established by the discrete element method (DEM), which showed that the supporting effect by the expanded gangue was well functioning. The gob-side entry was in pressure-relief surroundings and featured in the lesser deformation. The roof presplitting design method was presented and validated with a field test. The test illustrated that RPGER reduced the mining pressure on the retained entry side. The expanded gangue on the entry side was gradually compacted. It is the compaction process that played the role of reliving mining pressure, and the compacted gangue became the effective rib of the gob-side entry. The retained entry in the pressure-relief surroundings would stabilize a lagging distance behind the working face. The gob-side entry after stabilization met the entry retaining and the safety production requirements. This work illustrates the mechanism of RPGER and validates its feasibility and efficiency.
\end{abstract}

Keywords: roof presplitting; gob-side entry retaining; retaining mechanism; numerical simulation; field test

\section{Introduction}

Coal as a non-renewable energy has been consumed for a variety of purposes regarding industry and livelihood [1]. Coal resources feature in the worldwide distribution and widespread availability, which made it become the significant role for increasing the national economy as well, either directly through their own value or indirectly through the international trade [2]. In 2013, both the global production and consumption of coal reached their maximum levels, and from then global regions have been turning to lower their level of coal production and consumption due to the environmental issues 
and the renewable energy penetration [3,4]. However, a further bounce back in coal was continually seen in 2018 based on the slight growth in 2017. Both coal consumption (1.4\%) and production $(4.3 \%)$ increases at their fastest rates for five years [5]. The major contributors were concentrated in developing countries-especially India and China—together accounting for the majority of the gains in both consumption and production. Interestingly, US coal producers increased their production for exporting to Asia despite a further fall in domestic consumption [6,7]. All of the growth in global coal consumption went into the power sector. Renewable energy grew quickly, but not quickly enough to meet all the growth for power demand, and coal was sucked into the power sector as a balancing fuel $[5,8]$. Therefore, coal as the crucial primary energy has been playing a dominant role in the development of the global economy and construction, which will last for a considerable time in future.

Longwall coal mining is an efficient method for coal production, and it has a development history for more than 200 years [9]. Nowadays, longwall mining has been extensively used to meet the huge demand for coal. However, coal as a non-renewable mineral resource faces the resource depletion after massive long-term exploitation [10]. The conventional longwall mining features the pillar layout and leaves many coal pillars underground unrecovered. Since the 1950s, a gob-side entry retaining (GER) method has begun to spring up in the longwall mining industry, mainly in Poland, the United Kingdom, Russia, Germany and China [11]. This GER method retains the head entry of the current panel and reuses the retained entry for the next adjacent panel mining - the key of which is setting an artificial wall by filling material [12]. As shown in Figure 1, material filling for gob-side entry retaining (MFGER) arranges the artificial filling wall after mining on the gob side. Thus, the wall becomes the rib of the gob-side entry. After the current panel mining, the retained entry can serve the next adjacent panel mining, as shown in Figure 2a. Therefore, GER effectively improves the recovery ratio of coal resources and reduces entry excavation. However, the gob-side entry under the MFGER approach is subject to large deformation due to its roof structure and stress transfer [13]. The dynamic pressure caused by the key block movement (Figure 1) acts on the gob-side entry, which often leads to uncontrollable rapid shrinkage of gob-side entry [14]. As the longwall mining face stretches to the deeper level, it is more challenging and harder to maintain a gob-side entry $[15,16]$. Besides, the mining geological conditions of coal seam are complex. The MFGER strategy should be specially studied according to the different conditions [11], such as the coal seam buried depth, roof lithology, mining height, and dip angle [17-21].

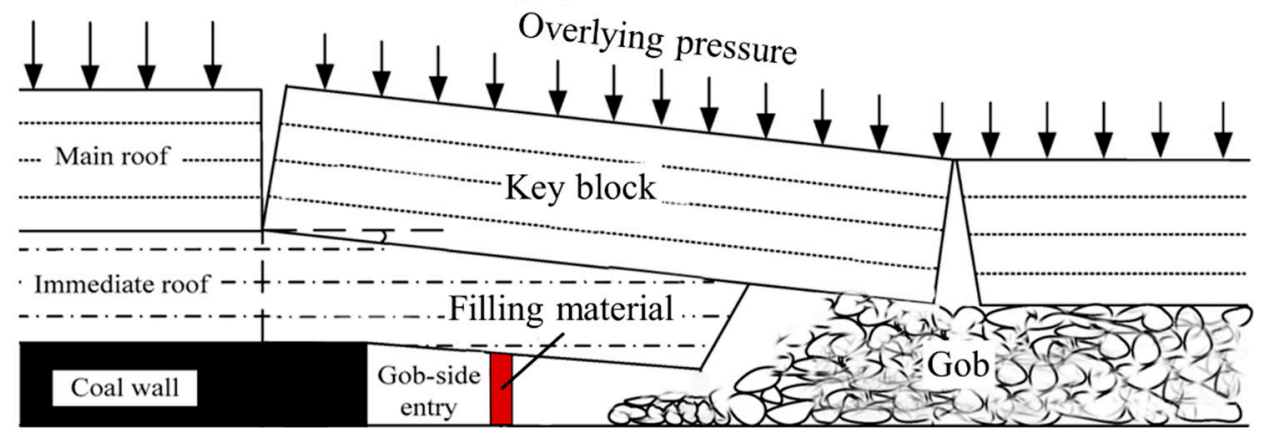

Figure 1. Diagram of material filling for gob-side entry retaining (MFGER).

In recent years, a novel GER method has emerged as a more practical and effective approach, which uses the roof presplitting technique instead of the material filling to retain the gob-side entry. As compared in Figure 2, roof presplitting for gob-side entry retaining (RPGER) cancels the wall setting and uses the presplitting technique to cut the roof. The gob rock roof collapses after mining along the roof presplitting line, and the caved gangue forms the retained entry rib by the gob-side support. In this way, RPGER simplifies the support procedure and material, and elevates the mining efficiency and continuity. Because of its simplicity and general applicability, RPGER is tested and adopted by many coalmines in China, and the application effects are satisified-even in complex geological 
conditions such as in the thick coal seam, deep buried depth, hard roof or compound roof and incline coal seam [22-25]. Zhang et al. (2011) [26] introduced the RPGER application on the protective seam mining for alleviating the problem of gas accumulation and burst, and the field test in the tail entry of the protective face 2422 in the Baijiao coalmine achieved good effect. Guo et al. (2016) [27] studied the key parameters of RPGER in the thin coal seam mining and successfully tested its application in the 3118 thin coal seam face of Jiayang coalmine. He et al. (2018) [28] studied the RFGEP application in a thick-seam fast-extracted mining face and tested industrial effect in the S1201 haulage entry of Ningtiaota coalmine. He et al. (2018) [29] studied the key parameters of RPGER in the deep medium-thickness coal seam mining and successfully tested its application in the 21304-working face of Chengiiao coalmine. However, the existing researches were mostly conducted for a particular case but barely attached the importance to the mechanism of RPGER. The understanding and exploration on the RPGER mechanism are vital for the technical improvement and promotion. Especially as the mining depth increases, the complicated stress environment will pose a new challenge to the RPGER application. Therefore, this work established a study of the RPGER approach, proceeded from its principle, established the roof presplitting design method, and explored its GER mechanism.

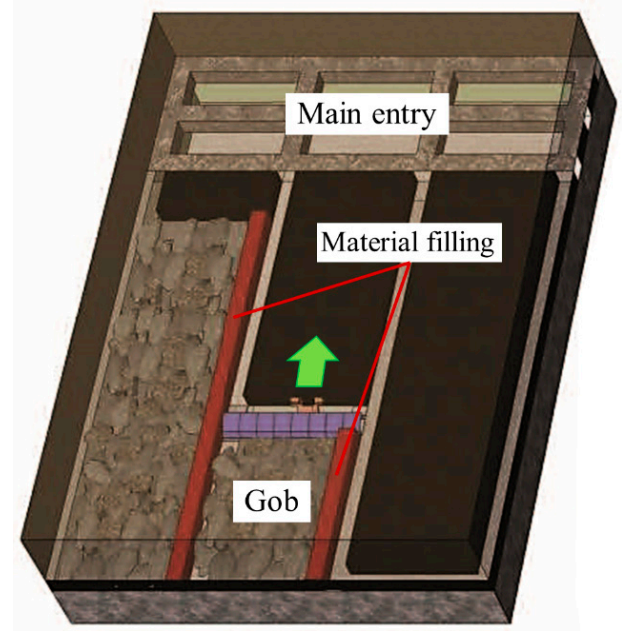

(a)

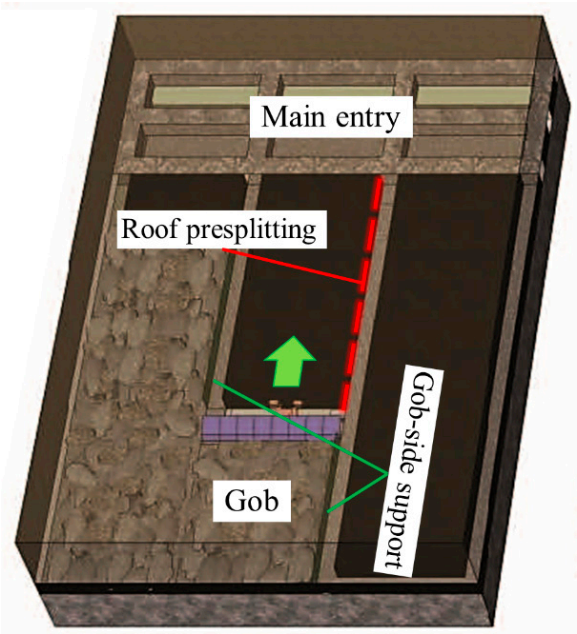

(b)

Figure 2. Different GER approach. (a) Material filling; (b) roof presplitting.

\section{RPGER Approach}

\subsection{Roof Presplitting}

The roof presplitting adopts the directional cumulative blasting technique, which is a precise tensile blasting method to generate directional cracks between the boreholes. The blasting principle is illustrated in Figure 3. Under the guidance of the bilateral energy-accumulation tube, a high-energy jet flow unloads from both sides of the borehole. The jet flow first grooves the surrounding rock. Considering the rock nature of high compressive resistance but low tensile resistance, these grooves develop the tensile fractures continuously by the cumulative tension effect. This effect attenuates as the increasing distance from the borehole center. In the end, the directional tensile crack ends when the tension is smaller than the rock tensile strength. Therefore, when multiple boreholes are set in a line, and the energy unloading direction is in keeping with the connecting line of the boreholes, a continuous directional crack is formed in the rock mass. In the RPGER approach, we utilize this blasting technique to split the rock roof before the mining. 

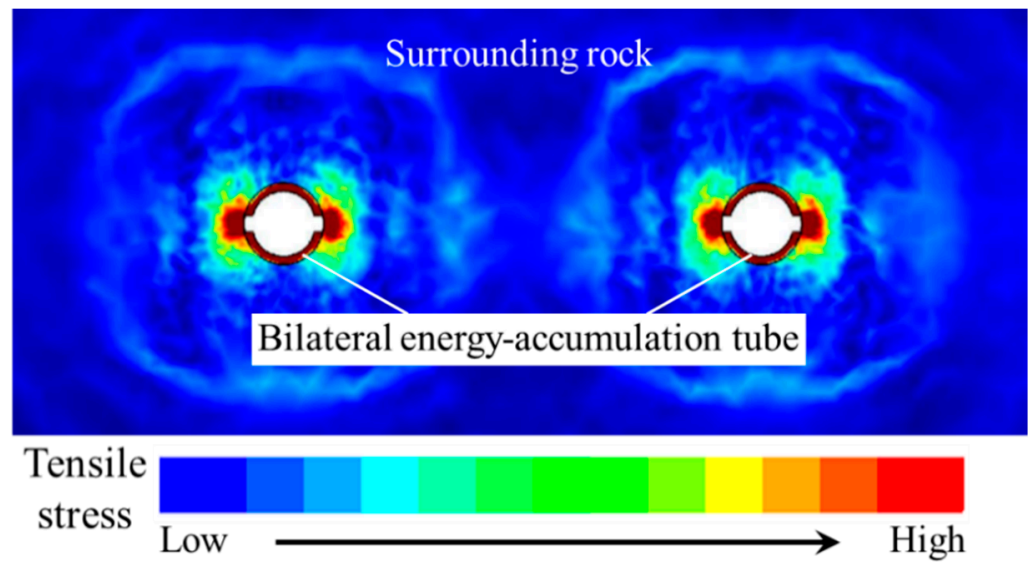

(a)

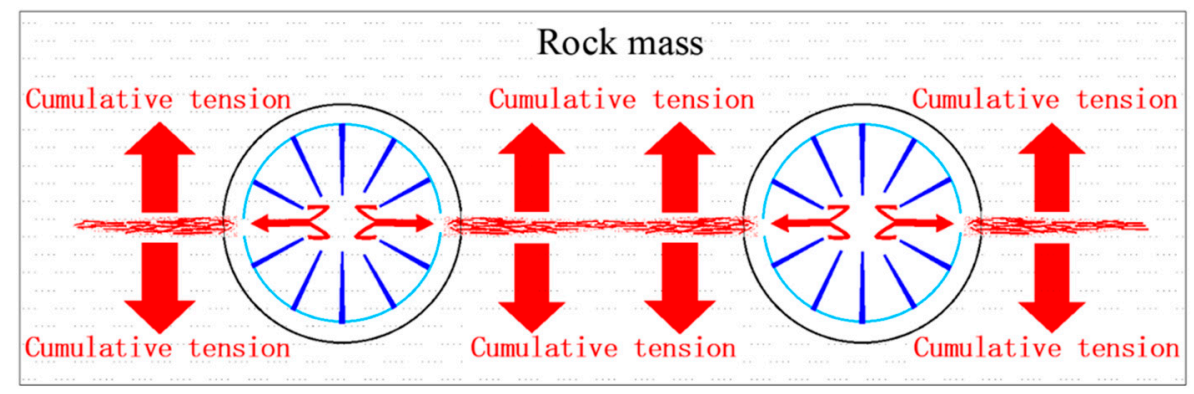

(b)

Figure 3. Directional tensile blasting principle. (a) Blasting stress field; (b) mechanical model.

\subsection{RPGER Principle}

The RPGER approach uses the directional cumulative blasting technique to presplit the entry roof on the gob side, which cuts off the rock roof connection and separates the rock roof between the gob-side entry and the gob. As pictured in Figure 4, the roof presplitting is set at a certain height with an angle. Because the roof has been cut apart along the presplitting line, the gob roof will cave spontaneously when the coal seam is mined out. The volume of the caved rock mass will increase due to the rock broken-expansion nature. Therefore, the expanded rock mass can be used as the potential supporting body against the overlying movement, and the rock mass forms the natural entry rib with the help of the gob-side support. These effects avoid the trouble of setting the artificial filling material and create pressure-relief surroundings for the gob-side entry retaining.

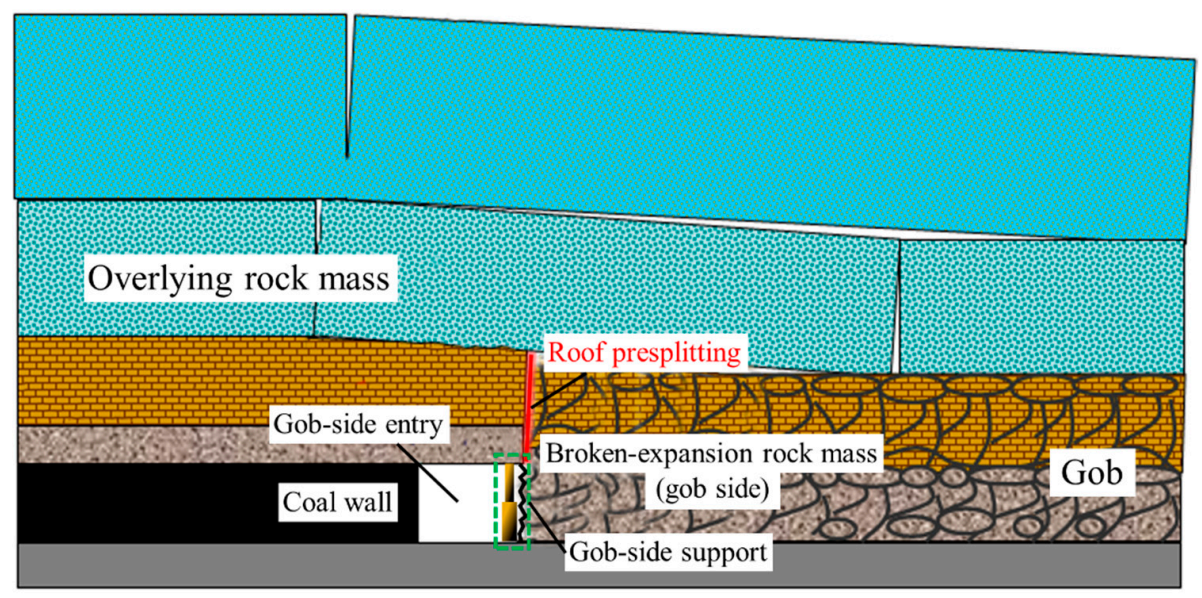

Figure 4. Schematic diagram of the RPGER approach. 


\subsection{Numerical Simulating Effect of RPGER}

\subsubsection{Numerical Model}

To investigate the surrounding rock movement in the RPGER approach, we established the discrete element model in two-dimension by UDEC program. UDEC is designed for simulating the response of the discontinuous material under the static or dynamic load. The rock mass with fractures such as joints and bedding is the typical discontinuous material. Discontinuities therein are treated as the boundary surface between the generated blocks, which can be rigid or deformable body, and these blocks can move, slip and rotate along the discontinuities in a large scale [30]. Considering the potential multiphysics change in the actual situation [31,32], the block adopts the deformable body and the calculating step was appropriately set as 5000, which helps observe the different regional response of rock blocks under RPGER. As shown in Figure 5, the model size was $200 \mathrm{~m} \times 60 \mathrm{~m}$ and the dimension of the gob-side entry was $5 \mathrm{~m} \times 2.5 \mathrm{~m}$. The roof presplitting height was set as $7 \mathrm{~m}$. Because the study objects were centered on the roof movement above the coal seam, the model grids were compactly generated and became thinner from the bottom up; the grid size was categorized according to the formation type. The model boundaries were fixed except for the upper boundary. The overlying pressure was set to $0.25 \mathrm{MPa}$, which is equivalent to $10 \mathrm{~m}$-thick strata. The constitutive model of the rock material was the Mohr-Coulomb model. The joint model adopted the Coulomb-Slip model in the surface contact. This joint model considers the elastic stiffness, the friction, the cohesion and the dilatancy, etc., which is commonly used in the underground rock excavation simulation [33]. The model mechanical parameters of the rock mass and joint are listed in Tables 1 and 2, respectively.

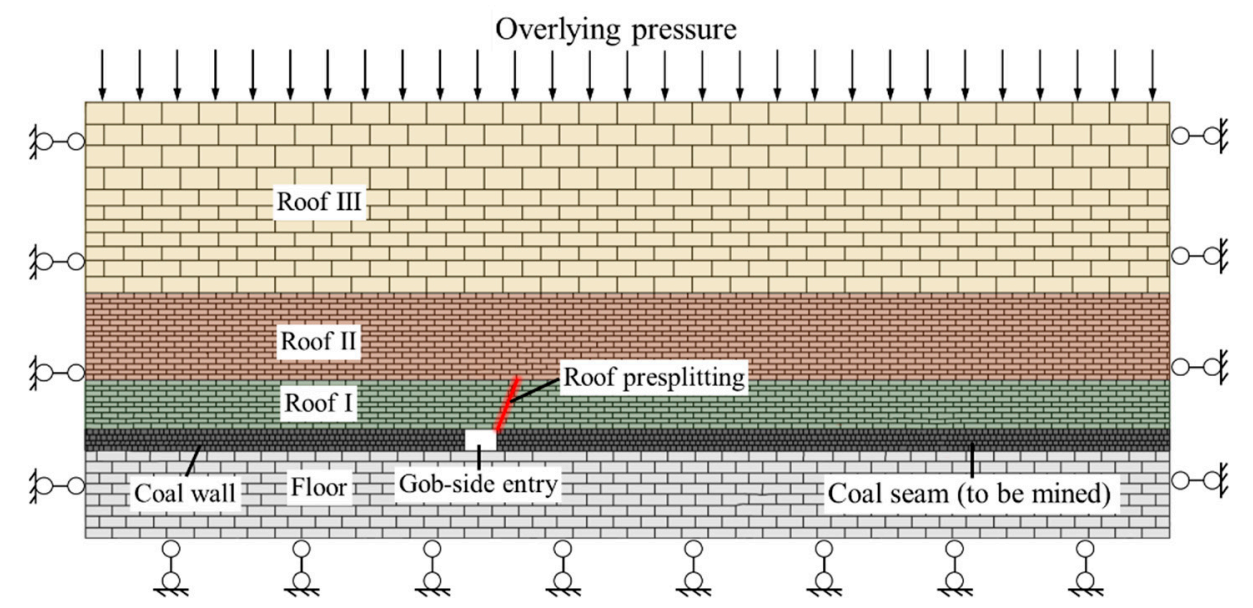

Figure 5. Numerical grid model.

Table 1. Rock mechanical parameters in model.

\begin{tabular}{|c|c|c|c|c|c|}
\hline Rock Strata & Density/(kg/m $\left.\mathrm{m}^{3}\right)$ & $\begin{array}{c}\text { Elasticity } \\
\text { Modulus (GPa) }\end{array}$ & $\begin{array}{l}\text { Friction } \\
\text { (deg) }\end{array}$ & $\begin{array}{l}\text { Cohesion } \\
\text { (MPa) }\end{array}$ & $\begin{array}{c}\text { Tensile Strength } \\
\text { (MPa) }\end{array}$ \\
\hline Roof III & 2550 & 18.6 & 33 & 2.6 & 1.18 \\
\hline Roof II & 2600 & 19.4 & 32 & 2.8 & 1.24 \\
\hline Roof I & 2750 & 22.6 & 30 & 3.2 & 1.60 \\
\hline Coal & 1500 & 4.0 & 22 & 0.8 & 0.36 \\
\hline Floor & 2550 & 18.2 & 30 & 2.4 & 1.12 \\
\hline
\end{tabular}


Table 2. Rock joint plane mechanical parameters in model.

\begin{tabular}{ccccc}
\hline Rock Strata & $\begin{array}{c}\text { Normal Stiffness } \\
\text { (GPa) }\end{array}$ & $\begin{array}{c}\text { Sheer Stiffness } \\
\text { (GPa) }\end{array}$ & Friction (deg) & Cohesion (MPa) \\
\hline Roof III & 2.2 & 1.1 & 5 & 0.03 \\
Roof II & 2.7 & 1.4 & 9 & 0.04 \\
Roof I & 3.2 & 2.6 & 10 & 0.02 \\
Coal & 0.6 & 3.8 & 3 & 0 \\
Floor & 2.6 & 1.2 & 8 & 0.04 \\
\hline
\end{tabular}

\subsubsection{Simulation Results}

The numerical simulation effect was shown in Figure 6. From the holistic perspective, the upper roof displacement on the right of the dashed white line was clearly greater than the left side, and the roof separation occurred on the right side. This illustrates that the caved rock mass close to the entry expanded effectively, and the expanded rock material filled the mining void that provided the resistance against the upper roof movement. By enlarging the gob-side entry part, we can see that the gob roof was apart with the entry roof significantly along the presplitting line; the rock mass within the presplitting height broke down while the entry roof was comparatively intact. The numerical results show that the displacement of the gob-side entry roof was $0 \sim 0.5 \mathrm{~m}$, and the immediate part and most of the entry roof were only in the minimum scope of $0 \sim 0.25 \mathrm{~m}$. Therefore, the RPGER approach not only solves the entry rib formation but also provides a pressure-relief environment to help the entry retaining.

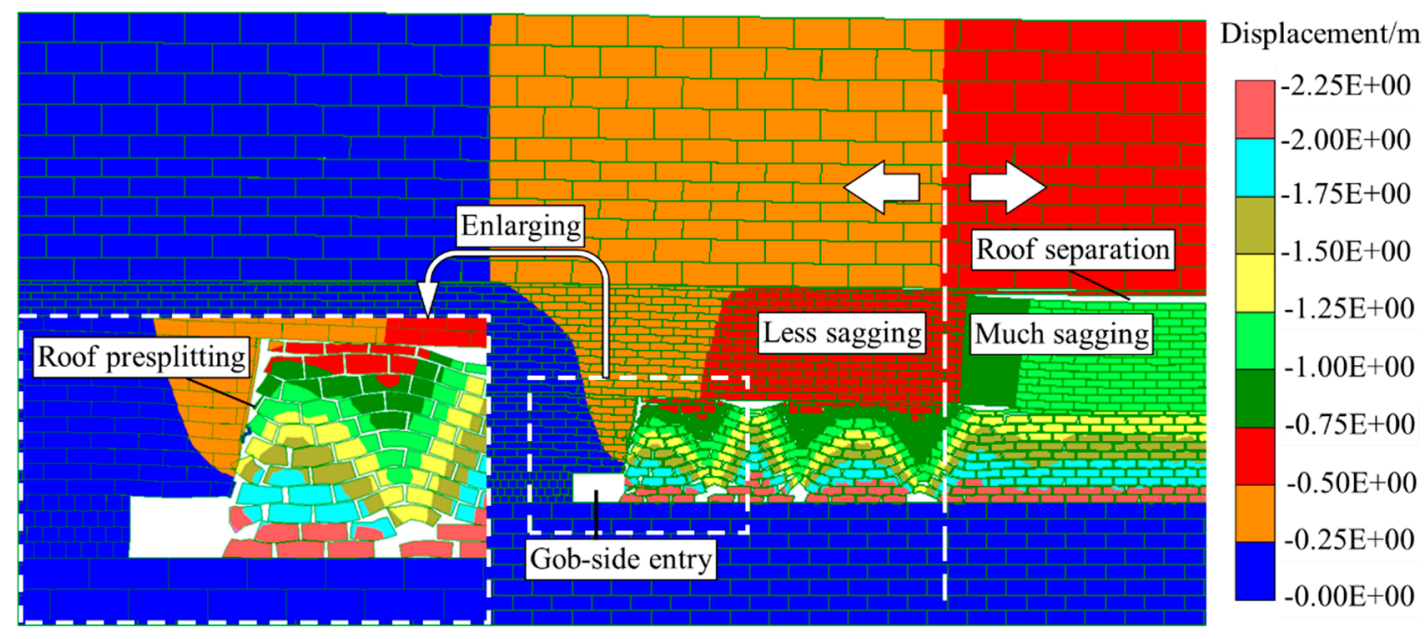

Figure 6. Numerical simulation result of surrounding rock movement and vertical displacement.

\section{Field Test}

\subsection{Geological Condition}

To validate the applicability and effectiveness of the RPGER approach, we conducted a field test in the Baoshan coalmine, Inner Mongolia, China. As shown in Figure 7a, the 6301 mining panel finished the extraction, and the test was conducted during the mining process of the 6302 panel. Therefore, the RPGER approach was applied to the 6302 tail entry. The 6302 mining panel was $200 \mathrm{~m}$ wide along the dip and $890 \mathrm{~m}$ long along the strike. The roof presplitting work was progressed inside along the strike direction of the tail entry before mining. Figure $7 \mathrm{~b}$ shows the stratigraphic column of the experimental mining panel. The mined coal seam was \#6 coal with a mean thickness of $1.6 \mathrm{~m}$. The immediate floor was $3 \mathrm{~m}$-thick sandy mudstone; the lower floor was $5.11 \mathrm{~m}$-thick medium sandstone. The immediate roof was $3.78 \mathrm{~m}$-thick fine sandstone, and the upper roof was 
sandy mudstone and fine sandstone with the average thicknesses of $23.2 \mathrm{~m}$ and $13.92 \mathrm{~m}$, respectively. Additionally, the average buried depth of the coal seam was $60 \mathrm{~m}$, and the average inclination was $2^{\circ}$.

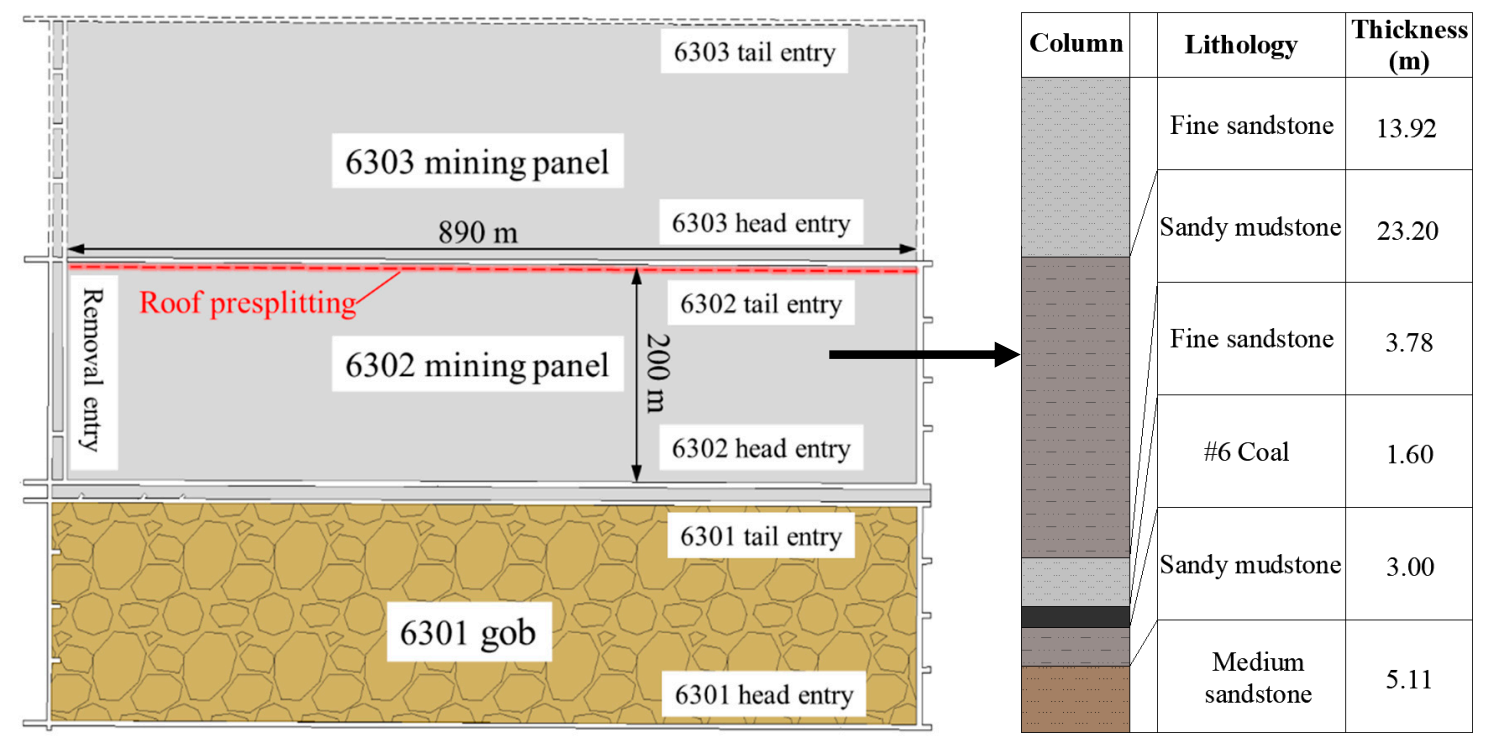

(a)

(b)

Figure 7. Site geological conditions. (a) Mining panel layout; (b) stratigraphic column of the 6302 mining panel.

\subsection{Test Design}

\subsubsection{Presplitting Angle}

The rock mass has its own mechanical properties and varies greatly from site to site. Therefore, the roof presplitting angle should be considered according to the site geological conditions. As illustrated in Section 2.2 (the RPGER principle), the presplitting position is on the gob side of the entry roof. To make the rock material within the presplitting height caves smoothly, the presplitting line should be angled at a proper degree to the gob side. According to the voussoir beam theory and the "S-R" stability principle, the fracture surface position varies in the interacted rock blocks due to the existing of initial cracks, while the roof presplitting defines the fracture surface before the rock breaks. As shown in Figure 8, the presplitting angle is $\theta$ between the presplitting line and the vertical direction. The horizontal thrust $T$ and the shear force $R_{A-B}$ are applied on the occlusal point of fractured rock blocks. The condition of block B keeping in balance is

$$
\left(T \cos \theta-R_{A-B} \sin \theta\right) \cdot \tan \varphi \geq R_{A-B} \cos \theta+T \sin \theta,
$$

where $\varphi$ is the friction angle of the rock mass. According to the whole structure model of the voussoir beam [34], the thrust $T$ and the shear force $R_{A-B}$ can be separately expressed as

$$
T=\frac{L_{B} Q_{B}}{2\left(h-s_{B}\right)},
$$

where $L_{B}$ is the friction angle of the rock mass; $Q_{B}$ is the weight of block $B ; h$ is the block thickness; $s_{B}$ is the rotational sinking value of block $B$.

$$
R_{A-B}=Q_{B} .
$$

Substituting Equations (2) and (3) into (1), the presplitting angle $\theta$ is calculated as

$$
\theta \geq \varphi-\arctan \frac{2\left(h-s_{B}\right)}{L_{B}} .
$$


According to the geological parameters on the test site, the parameters therein were $\varphi=30^{\circ}$, $h=3.78 \mathrm{~m}, s_{B}=1.6 \mathrm{~m}$ and $L_{B}=15.5 \mathrm{~m} ; \theta \geq 14.28^{\circ}$ was obtained. The presplitting angle in the engineering test was determined to be $15^{\circ}$.

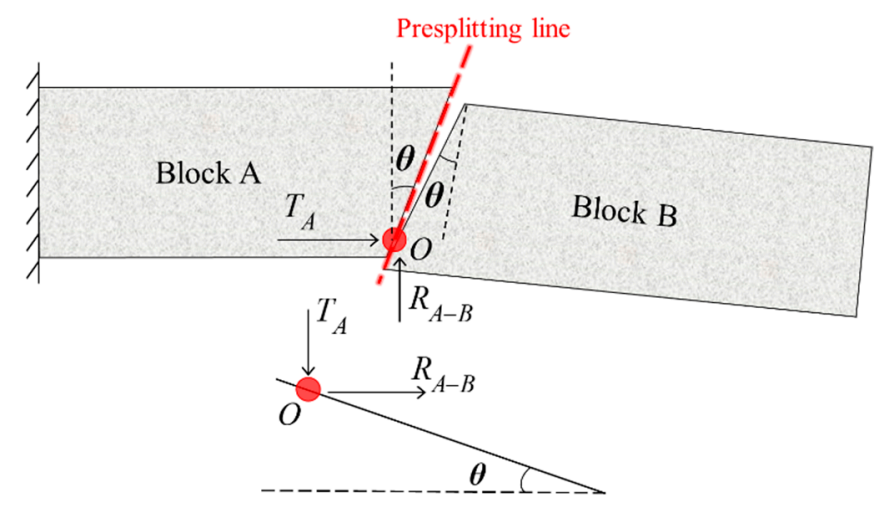

Figure 8. Presplitting rock blocks mechanical model.

\subsubsection{Presplitting Length}

The presplitting height is the key factor in the improvement of the entry pressure surroundings. The immediate roof caving height generally cannot fill the mining void during the usual mining process. This leads to a gap existing between the gangue and the upper strata. The gap height $\Delta \mathrm{h}$ can be expressed as

$$
\Delta h=m-h_{i}(b-1),
$$

where $m$ is the mining height, $h_{i}$ is the height of the immediate roof and $b$ is the bulking factor of the broken rock mass.

This gap provides conditions for the bending-sinkage movement of the upper strata, which causes serious mine-pressure behavior in the gob-side entry. The roof presplitting cleverly utilizes the broken-expansion behavior of the rock mass to make up the gap so as to reduce the mine pressure. The presplitting length $L$ should generally meet

$$
L \geq \frac{m}{(b-1) \cos \theta} .
$$

When the gob is filled with the broken rock mass, the strata subsides slightly, and the disorderly stacked rock is compacted accordingly. Substituting the related parameters in the field into Equation (6), where $m=1.6 \mathrm{~m}, b=1.35$ and $\theta=15^{\circ}$, we got $L \geq 4.73 \mathrm{~m}$. The presplitting length in the engineering test was determined to be $5 \mathrm{~m}$. The roof presplitting design sketch on site is shown in Figure 9. The gob-side support adopted the supporting combination of "Hydraulic prop + Double U-steel + Diamond mesh," which blocked gangue into the entry and integrated the rock being the entry rib. The roof support adopted the supporting combination of "Constant-resistance large-deformation (CRLD) anchor + Metal bolt + Metal mesh", which ensures the roof integrity and safety during the RPGER process. 


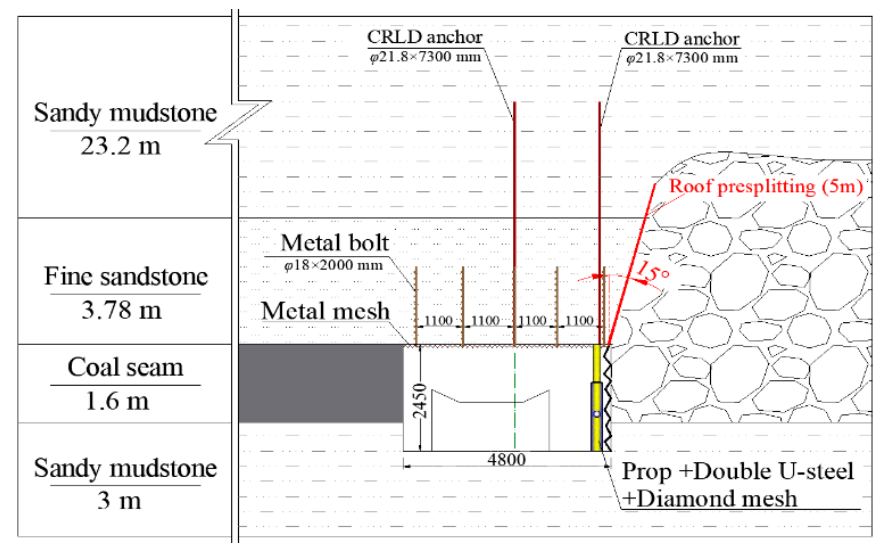

Figure 9. Roof presplitting design and entry support pattern.

\subsection{Test Effect}

\subsubsection{Roof Splitting Effect}

To ensure that the roof was separated successfully by the directional blasting, we first used the Exib borehole peeping instrument to observe the crack generation after the blasting. As shown in Figure 10a, the camera probe gradually moved into the borehole from the bottom and recorded the hole image in real time. The continuously recorded image was stored in the equipment host. Through the interaction with the computer, we obtained the blasting hole imaging. As shown in Figure 10b, the round surface was developed in a plane. In the charge segment $(2.0-5.0 \mathrm{~m})$, two apparent directional cracks extended along the axis of borehole depth.

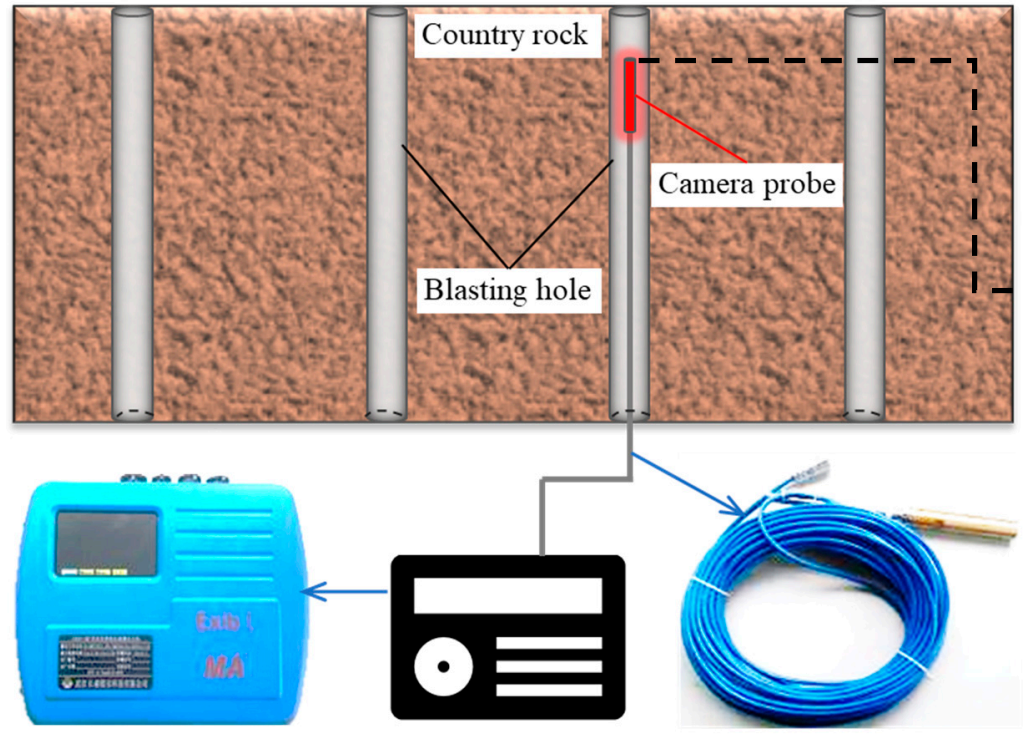

(a)

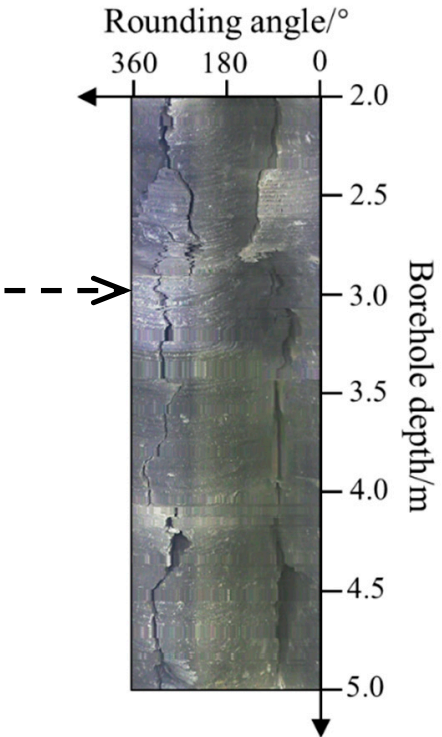

(b)

Figure 10. Borehole peeping. (a) Mining panel layout; (b) stratigraphic column of the 6302 mining panel.

When the roof was presplit effectively, the gob roof would cave along the splitting line as the mining face advanced. As shown in Figure 11, we observed the rock mass caving situation on the gob side through the metal mesh and found that the half borehole was on the collapsed rock. This phenomenon illustrated that a smooth weak plane was formed along the borehole line by the directional blasting. When the mining void was formed, the gob roof collapsed along the weak plane. The half-hole stayed in the original position of the entry roof, and the other half part was in the 
collapsed rock mass. For the jointed rock mass (Figure 11a), some blasting derivative cracks existed on the splitting plane due to the guidance of pre-existing fractures in rock mass. For the intact rock mass (Figure 11b), the splitting plane was a smoother and more intact plane. Meanwhile, we could see that no other obvious cracks were formed on the hole surface, which illustrated the energy-guidance function of the bilateral energy-accumulation tube (Figure 3).

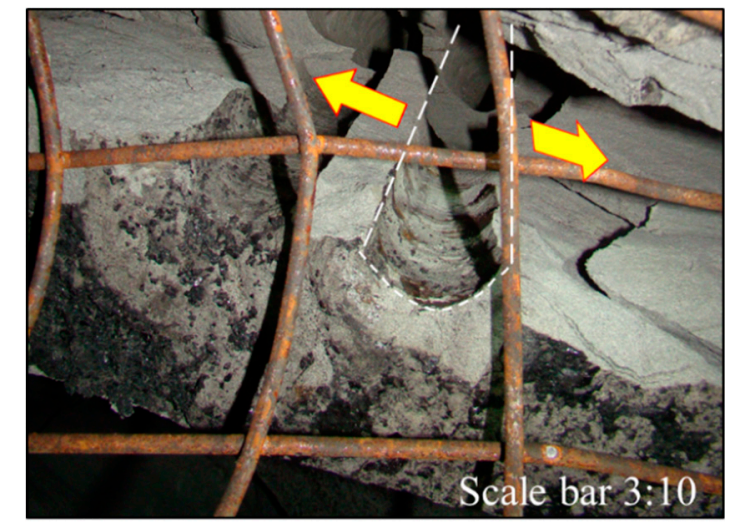

(a)

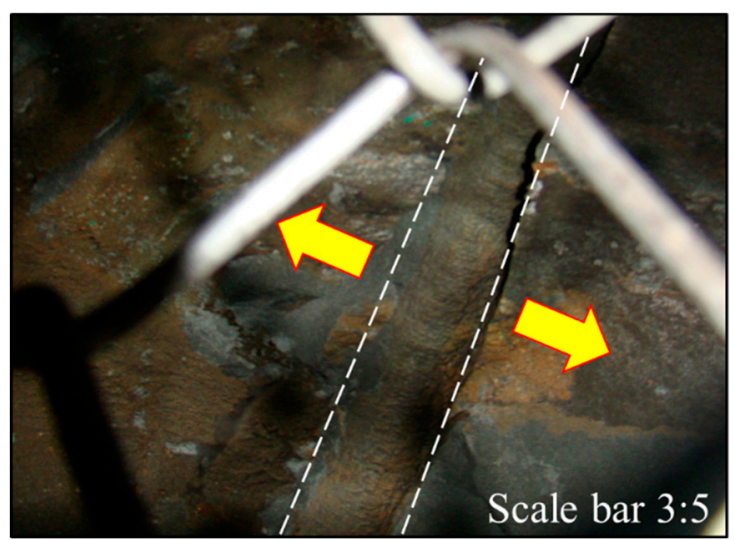

(b)

Figure 11. Roof splitting effect shown in the gob. (a) Jointed rock mass; (b) intact rock mass.

\subsubsection{Mining Pressure}

To investigate the RPGER pressure relief effect, we monitored the hydraulic support pressure changes in different positions of the working face. As known from Section 2.3.2, the caved gob-roof close to the roof presplitting line fully expands to resist the upper roof motion. As the distance from the presplitting plane increases, the pressure-relief effect reduces so as to the roof separation. Therefore, we chose the pressure monitoring results of the hydraulic support on the roof non-presplitting side and the roof presplitting side for analyses. The pressure change of the whole support on the roof non-presplitting side was illustrated in Figure 12a. During the $60 \mathrm{~m}$ advanced distance, the maximum support pressure from the roof fracturing was $6667 \mathrm{kN}$ and the average pressure was $4488 \mathrm{kN}$. As for the support on the roof presplitting side (Figure 12b), the maximum support pressure was $5549 \mathrm{kN}$ and the average pressure was $3641 \mathrm{kN}$ during the same $60 \mathrm{~m}$ advanced distance. With the help of the caved gangue support, the maximum pressure decreased by $16.8 \%$ and the average pressure decreased by $18.9 \%$. These results showed that the RPGER approach changed the fractured roof action mode on the roof presplitting side. In the mining face advanced direction, the mining pressure directly loaded objects changed from the "coal wall + hydraulic support" to the combination of "coal wall + hydraulic support + gangue". As a result, pressure relief surroundings were created for the entry retaining.

Meanwhile, the bearing rule of the expanded gangue was investigated on the test site. The bearing rule can be reflected from the law of the gangue compressive deformation, so we designed the in-situ labeling method to monitor the broken-expansion coefficient of the gangue. First, we made a mark in the presplitting borehole at a particular depth $h_{0}$. When the coal mass below was mined out, the gob roof caved and the initial stack height of the mark on the half-hole surface was $h_{1}$. Then, we continuously recorded the stack heights as $h_{2}, h_{3}, \ldots, h_{n}$ with the mining face advanced until the height did not change anymore. The broken-expansion coefficient $\mathrm{b}$ was calculated as $b=h_{i} / h_{0}$ $(i=1,2, \ldots, n)$. Figure 13 showed the dynamic change of the gangue broken-expansion coefficient as the working face advanced. The coefficient change curve was characterized by the trend of "rapid decrease - moderate decrease - stable" as the working face advanced. At the initial state, the gangue volume increased by 1.53 times. Then, the gangue as the supporting body was compressed due to the roof weighting. In the beginning stage, the monitoring position was close to the working face, and the dynamic pressure effect there was significant. Besides, the initial caved rock mass piled loosely. So, 
the gangue volume decreased rapidly during the initial compression. As the working face advanced away from the monitoring position, the dynamic pressure influence weakened. The rock mass was compacted gradually, and the compressible space shrank. Therefore, the coefficient decreased slowly. Finally, the gangue expanded and stabilized at a certain broken-expansion coefficient, around 1.34. The stabilization distance on site was around $100 \mathrm{~m}$ behind the working face. The results showed that the roof weighting pressure is finite, and the gangue can be the active supporting body in the dynamic pressure zone. When the gangue was compacted in the stabilization zone, it can be the effective rib of the retaining entry.

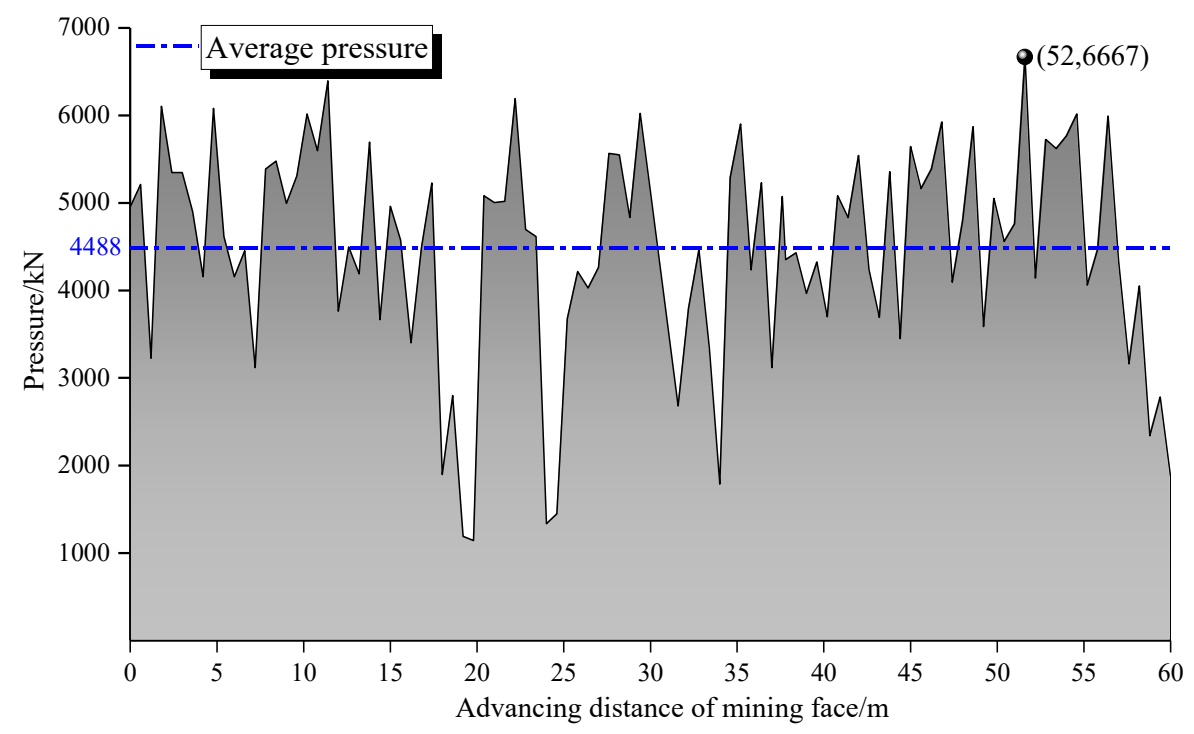

(a)

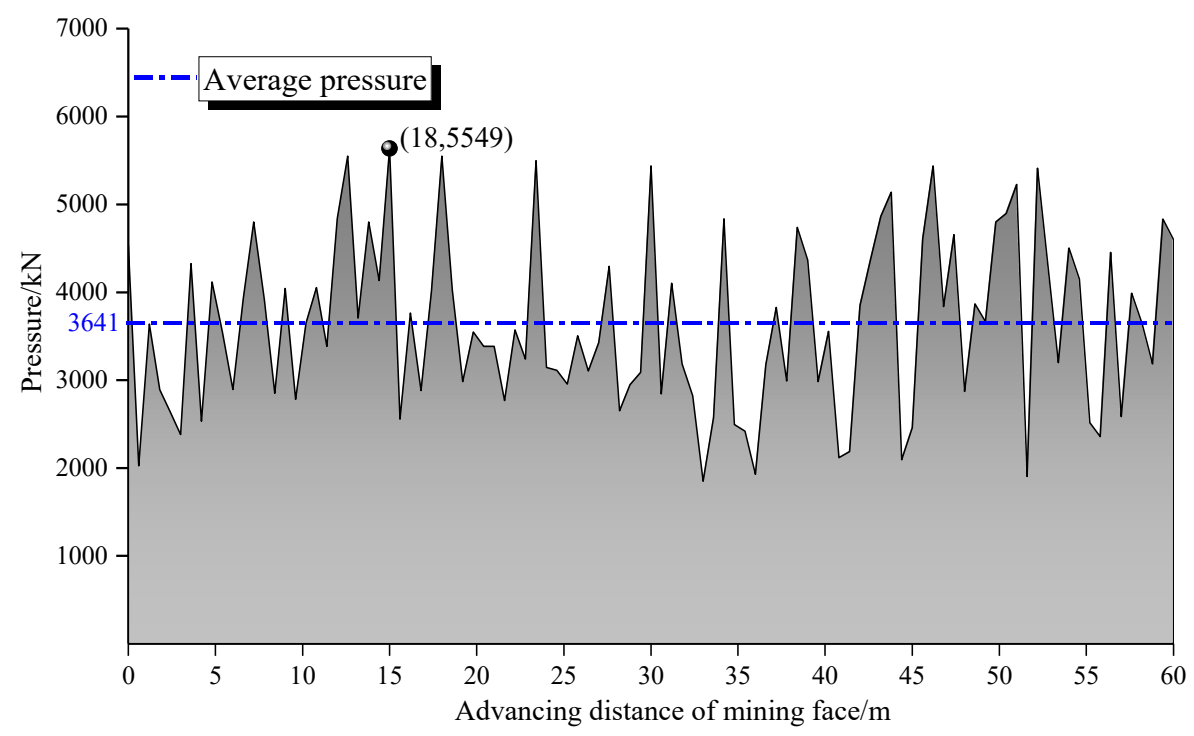

(b)

Figure 12. Hydraulic support pressure monitoring results. (a) Roof non-presplitting side; (b) roof presplitting side. 


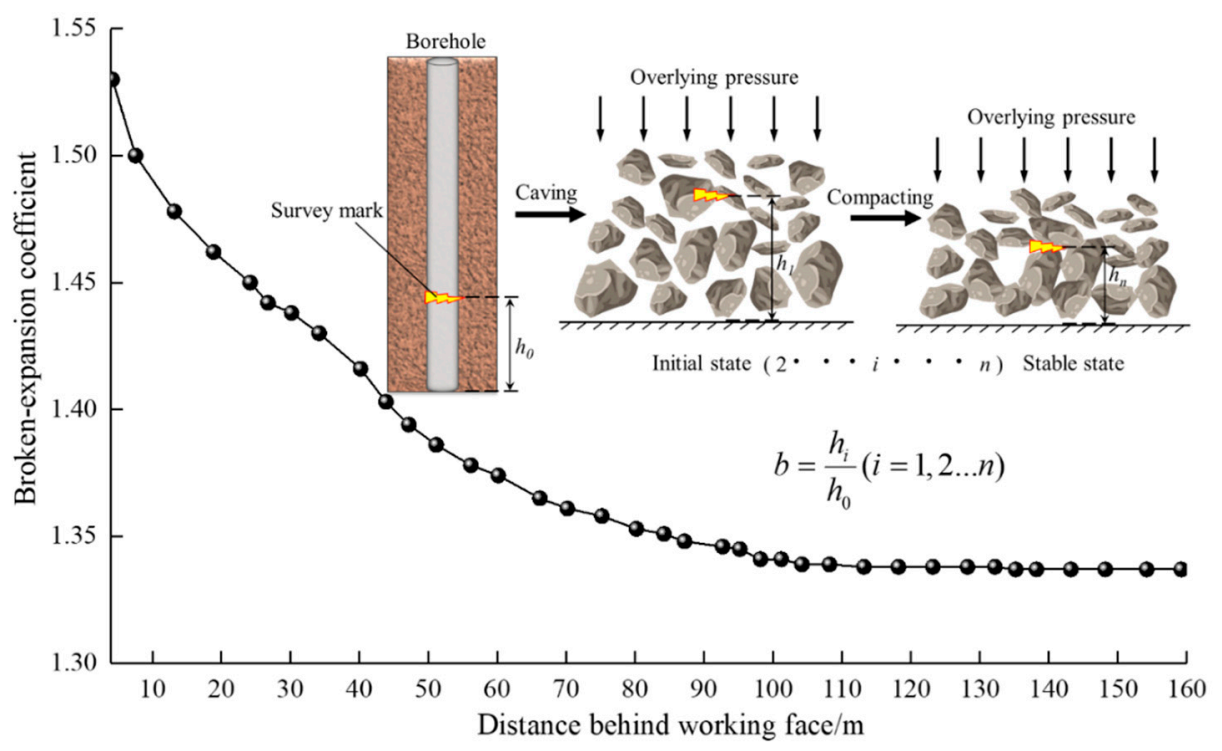

Figure 13. Broken-expansion coefficient change.

\subsubsection{Gob-Side Entry Deformation}

The gob-side retained entry deformation is an important indicator for evaluating an entry retaining method. A stable and less deforming entry is preferred for the mining production and safety. To investigate the gob-side entry deformation rule and its stability under the RPGER approach, we monitored the entry vertical and horizontal displacement during the retaining process. The vertical displacement monitoring included three indexes: the roof subsidence, the floor heave and their algebraic sum (i.e., the roof-to-floor convergence). As shown in Figure 14a, the vertical displacement kept going up with the increasing distance behind away from the working face. When the working face was $148 \mathrm{~m}$ ahead of the monitoring point, the subsequent displacement did not increase anymore; the entry of the vertical direction there entered the stable state. In the entry-deforming stage, the roof subsidence was the principal component of the roof-to-floor convergence, and the subsidence rapidly increased within the first $67 \mathrm{~m}$. Compared to the roof deformation, the floor heave displacement increased gently over the process, and the increase in the latter half of the deforming stage was a little faster than the first half. Finally, the roof subsidence stabilized at $131 \mathrm{~mm}$, and the floor heave displacement stabilized at $81 \mathrm{~mm}$. The roof-to-floor convergence was $212 \mathrm{~mm}$. Figure $14 \mathrm{~b}$ shows the horizontal displacement variation of the gob-side entry as the working face advanced. The horizontal displacement monitoring likewise included three indexes: the gangue rib extrusion, the coal rib extrusion and their algebraic sum (i.e., the rib-to-rib convergence). As the lagging distance from the working face to the monitoring position increased, the horizontal displacement remained growth. When the lagging distance was $125 \mathrm{~m}$, the horizontal displacement ended up in the convergence, where the entry entered the stable state in the horizontal direction. In the deforming stage, the gangue extrusion was the major component of the rib-to-rib convergence. As the gangue was gradually compacted (Figure 13), the gangue rib deformation became stable to $86 \mathrm{~mm}$. The other component of the horizontal convergence (i.e., the coal rib deformation) stabilized at $53 \mathrm{~mm}$ with the weakening effect of the dynamic pressure. The ultimate rib-to-rib convergence was $139 \mathrm{~mm}$.

According to the above analysis of the entry deformation, the ultimate dimension of the gob-side entry was $2238 \mathrm{~mm}$ high and $4661 \mathrm{~mm}$ wide, which sufficiently met the entry retaining requirements for the next mining face production. Figure 15 shows the scenario of the gob-side entry onsite. Compared with the entry before mining, the entry was retained with high quality after the mining. The roof was still complete and flat; the gangue rib was integrally formed with the help of the gob-side support; the floor and the coal rib were well maintained. The gob-side entry met the safety production requirements. 


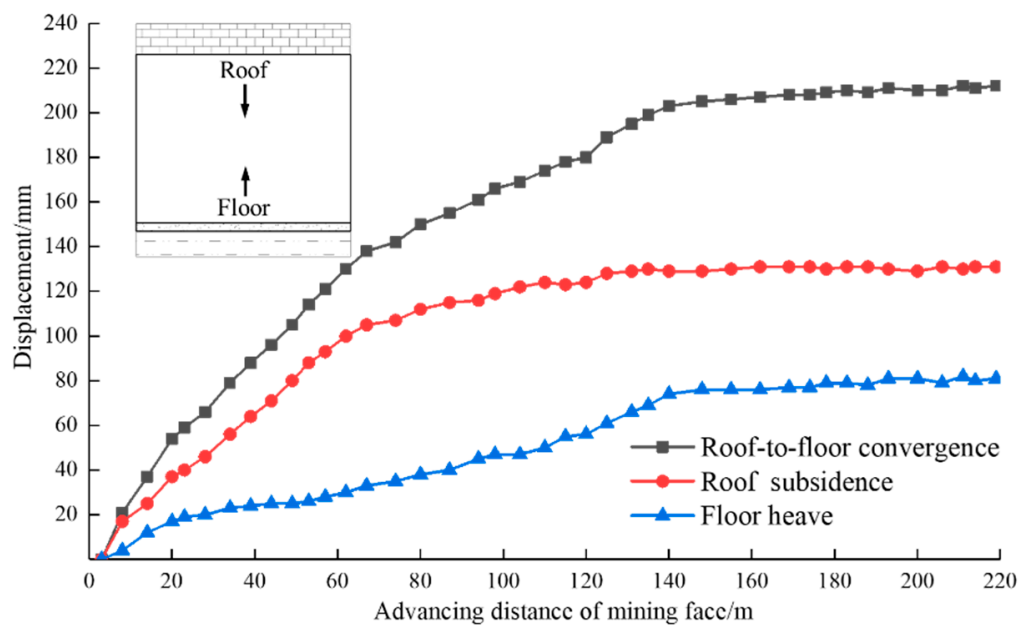

(a)

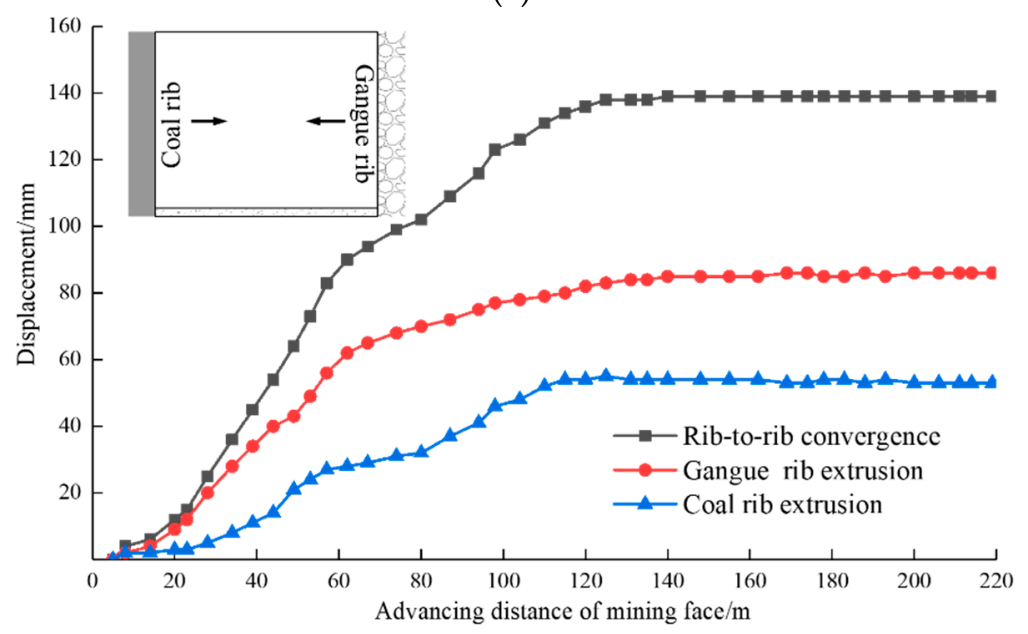

(b)

Figure 14. Gob-side entry deformation. (a) Vertical displacement; (b) horizontal displacement.

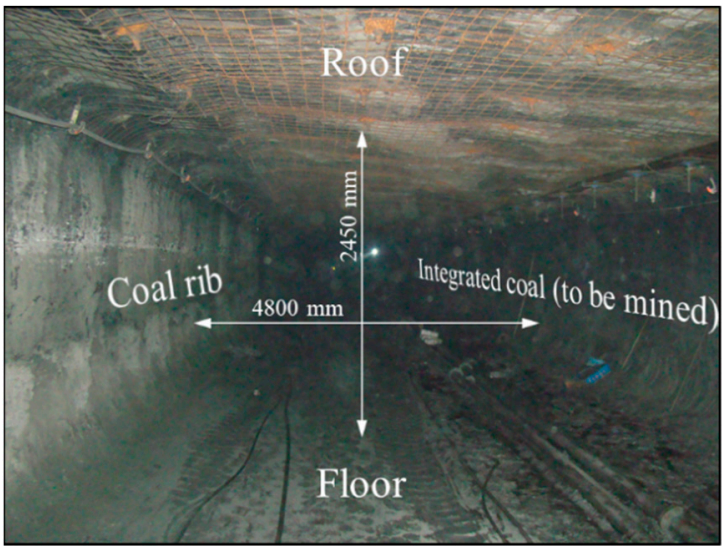

(a)

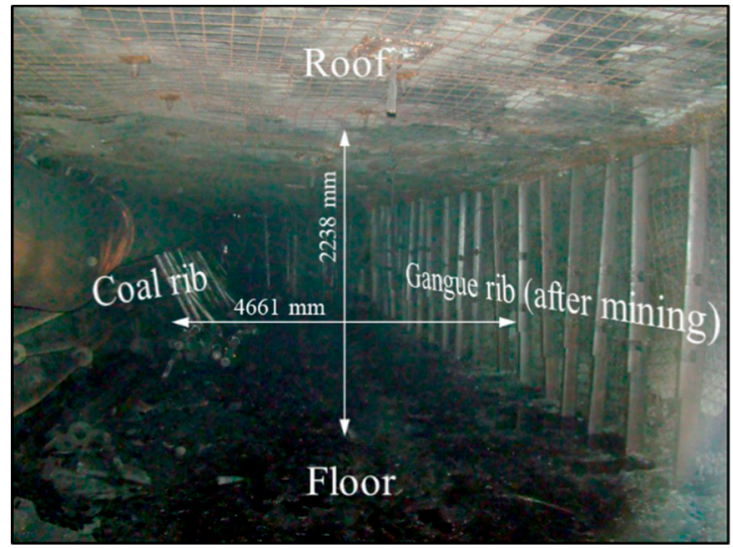

(b)

Figure 15. Gob-side entry under the RPGER approach. (a) Before retaining; (b) after retaining.

\section{Discussion and Conclusions}

This study investigates an innovative approach of presplitting roof for retaining the gob-side entry (RPGER). RPGER uses the directional cumulative blasting technique to split the entry roof before mining, thus cuting off the lower rock roof connection between the gob-side entry and the gob. The gob 
roof within the presplitting height caves spontaneously on the entry side after mining, and the caved gangue become the gob-side entry rib with the help of gob-side support. Meanwhile, the gob-side entry by RPGER is under the pressure relief surroundings, which is favorable for retaining the gob-side entry.

The numerical simulation of RPGER was conducted by the discrete element method. Simulation results verified the proposed approach. The caved gob roof on the entry side formed one entry rib and expanded to be the natural supporting body for resisting the upper roof movement. The strata sagging value on the entry side was significantly less than that on the deep gob side, and most of the gob-side entry roof was in the least deforming range at this strata system.

A field test was conducted to study the engineering application of the RPGER approach. According to the geological site conditions, the scientific presplitting angle and length were obtained through the derived Equations (4) and (6). Under the field construction, the roof presplitting could directionally cut apart the roof. The mining pressure on the entry side decreased due to the supporting effect of the broken-expansion rock mass within the presplitting height, and the average pressure was released by $18.9 \%$ in the field. During the pressure relief process, the gangue was gradually compacted to the stable state, thus becoming an effective rib of the gob-side entry. Meanwhile, the retained gob-side entry would go through a deforming period when the entry position was closely behind the working face. The roof subsidence was the major component of the vertical convergence, and the gangue rib extrusion was the major component of the horizontal convergence. The field test showed that the entry stabilization distance in the vertical direction was $148 \mathrm{~m}$ and in the horizontal direction was $125 \mathrm{~m}$. The vertical and horizontal displacement was $212 \mathrm{~mm}$ and $139 \mathrm{~mm}$, respectively. The gob-side entry after stabilization sufficiently met the entry retaining and the safety production requirements.

The study results provide an innovative approach of RPGER and potentially reveal its GER mechanism. Although different coalmines present significant variations of geological and mining conditions-which may lead to different design parameters and application effects of RPGER-it is vital to master the RPGER principle and mechanism for optimizing the entry retaining process and ensuring the entry safety. RPGER is in rapid development and promotion owing to its high usability and efficiency. It is noteworthy that the law of underground mining pressure under the complex geological and mining conditions is immensely complicated. Therefore, one potential research direction of RPGER in future is supposed to concern the applied research of RPGER in the high-stress environment.

Author Contributions: Conceptualization, M.H. and X.Z.; methodology, M.H., J.Y. and X.Z.; software, Y.G. and L.C.; validation, X.Z., Y.G. and J.H.; formal analysis, X.Z.; resources, M.H., J.Y. and Y.G.; writing-original draft preparation, X.Z.; writing-review and editing, J.H.; supervision, L.C.; project administration, J.Y.; funding acquisition, M.H., J.Y., X.Z. and Y.G.

Funding: This research was funded by the State Key Laboratory for Geomechanics and Deep Underground Engineering, China University of Mining and Technology, Beijing, grant number [SKLGDUEK1928], the State Key Research Development Program of China, grant number [2016YFC0600900], the Program of China Scholarship Council, grant number [201806430070], China Postdoctoral Science Foundation grant number [2019M650896], and the APC was funded by China University of Mining and Technology, Beijing, which are gratefully acknowledged.

Conflicts of Interest: The authors declare no conflict of interest.

\section{References}

1. Wolde-Rufael, Y. Coal consumption and economic growth revisited. Appl. Energ. 2010, 87, 160-167. [CrossRef]

2. Suárez-Ruiz, I.; Diez, M.A.; Rubiera, F. Coal. In New Trends in Coal Conversion; Woodhead Publishing: Cambridge, UK, 2019; pp. 1-30. ISBN 978-0-0810-2201-6.

3. Le Quéré, C.; Andrew, R.M.; Friedlingstein, P.; Sitch, S.; Pongratz, J.; Manning, A.C.; Korsbakken, J.I.; Peters, G.P.; Canadell, J.G.; Jackson, R.B. Global carbon budget 2017. Earth Syst. Sci. Data Discuss. 2017, 1-79. [CrossRef]

4. Wang, Q.; Li, R. Decline in China's coal consumption: An evidence of peak coal or a temporary blip? Energy Policy 2017, 108, 696-701. [CrossRef]

5. Dudley, B. BP Energy Outlook; Report-BP Energy Economics: London, UK, 2018; p. 9. 
6. Kimura, S.; Phoumin, H. Energy Outlook and Energy Saving Potential in East Asia 2019; Economic Research Institute for ASEAN and East Asia: Jakarta, Indonesia, 2019.

7. Mendelevitch, R.; Hauenstein, C.; Holz, F. The Death Spiral of Coal in the USA: Will New US Energy Policy Change the Tide? DIW Berlin Discussion Paper No. 1790; Elsevier: Amsterdam, Netherlands, 2019.

8. Stougie, L.; Giustozzi, N.; van der Kooi, H.; Stoppato, A. Environmental, economic and exergetic sustainability assessment of power generation from fossil and renewable energy sources. Int. J. Energy Res. 2018, 42, 2916-2926. [CrossRef]

9. Peng, S.S.; Chiang, H.S. Longwall Mining; Wiley Press: Hoboken, NJ, USA, 1984; ISBN 978-0-4292-6004-9.

10. Höök, M.; Zittel, W.; Schindler, J.; Aleklett, K. Global coal production outlooks based on a logistic model. Fuel 2010, 89, 3546-3558. [CrossRef]

11. Yang, H.; Cao, S.; Wang, S.; Fan, Y.; Wang, S.; Chen, X. Adaptation assessment of gob-side entry retaining based on geological factors. Eng. Geol. 2016, 209, 143-151. [CrossRef]

12. Tan, Y.L.; Yu, F.H.; Ning, J.G.; Zhao, T.B. Design and construction of entry retaining wall along a gob side under hard roof stratum. Int. J. Rock Mech. Min. Sci. 2015, 77, 115-121. [CrossRef]

13. Zhang, N.; Yuan, L.; Han, C.; Xue, J.; Kan, J. Stability and deformation of surrounding rock in pillarless gob-side entry retaining. Saf. Sci. 2012, 50, 593-599. [CrossRef]

14. Li, X.; Ju, M.; Yao, Q.; Zhou, J.; Chong, Z. Numerical Investigation of the Effect of the Location of Critical Rock Block Fracture on Crack Evolution in a Gob-side Filling Wall. Rock Mech. Rock Eng. 2015, 49, 1041-1058. [CrossRef]

15. Gong, P.; Ma, Z.; Ni, X.; Zhang, R. Floor heave mechanism of gob-side entry retaining with fully-mechanized backfilling mining. Energies 2017, 10, 2085. [CrossRef]

16. Brown, E.T. Progress and challenges in some areas of deep mining. Min. Technol. 2013, 121, $177-191$. [CrossRef]

17. Chang, Q.L.; Tang, W.J.; Xu, Y.; Zhou, H.Q. Research on the width of filling body in gob-side entry retaining with high-water materials. Int. J. Min. Sci. Technol. 2018, 28, 519-524. [CrossRef]

18. Yang, H.; Cao, S.; Li, Y.; Sun, C.; Guo, P. Soft roof failure mechanism and supporting method for gob-side entry retaining. Minerals 2015, 5, 707-722. [CrossRef]

19. Xue, J.; Duan, C. Technologies of gob-side entry retaining with no-pillar in condition of overlying and thick-hard roof. J. China Coal. Soc. 2014, 39, 378-383.

20. Xue, J.; Han, C. Strata behavior and control countermeasures for the gob-side entry retaining in the condition of large mining height. J. Min. Saf. Eng. 2012, 29, 466-473.

21. Yan, S.; Liu, T.X.; Bai, J.B.; Wu, W.D. Key parameters of gob-side entry retaining in a gassy and thin coal seam with hard roof. Processes 2018, 6, 51. [CrossRef]

22. Ma, Z.; Wang, J.; He, M.; Gao, Y.; Hu, J.; Wang, Q. Key Technologies and application test of an innovative noncoal pillar mining approach: A case study. Energies 2018, 11, 2853. [CrossRef]

23. He, M.; Gao, Y.; Yang, J.; Gong, W. An innovative approach for gob-side entry retaining in thick coal seam longwall mining. Energies 2017, 10, 1785. [CrossRef]

24. Hu, J.; He, M.; Wang, J.; Ma, Z.; Wang, Y.; Zhang, X. Key parameters of roof cutting of gob-side entry retaining in a deep inclined thick coal seam with hard roof. Energies 2019, 12, 934. [CrossRef]

25. Fan, D.; Liu, X.; Tan, Y.; Song, S.; Gu, Q.; Yan, L.; Xu, Q. Roof cutting parameters design for gob-side entry in deep coal mine: A case study. Energies 2019, 12, 2032. [CrossRef]

26. Zhang, G.; He, M.; Yu, X. Research on the technique of no-pillar mining with gobside entry formed by advanced roof caving in the protective seam in Baijiao coalmine. J. Min. Saf. Eng. 2011, 28, 511-516.

27. Guo, Z.; Wang, J.; Cao, T. Study on key parameters of automatic roadway with thin coal seam topping.pressure relief. J. China Univ. Min. Technol. 2016, 45, 879-885.

28. He, M.; Gao, Y.; Yang, J.; Wang, J.; Wang, Y.; Zhu, Z. Engineering experimentation of gob-side entry retaining formed by roof cutting and pressure release in a thick-seam fast-extracted mining face. Rock Soil. Mech. 2018, 39, 254-264.

29. He, M.; Ma, Z.; Guo, Z.; Chen, S. Key parameters of the gob-side entry retaining formed by roof cutting and pressure release in deep medium-thickness coal seams. J. China Univ. Min. Technol. 2018, 47, 468-477.

30. Itasca Consulting Group, Inc. UDEC-Universal Distinct Element Code, Version 7.0; User Manual; Itasca Consulting Group, Inc.: Minneapolis, MN, USA, 2018. 
31. Jia, B.; Tsau, J.S.; Barati, R. A workflow to estimate shale gas permeability variations during the production process. Fuel 2018, 220, 879-889. [CrossRef]

32. Jia, B.; Tsau, J.S.; Barati, R. Role of molecular diffusion in heterogeneous, naturally fractured shale reservoirs during CO2 huff-n-puff. J. Petroleum Sci. Eng. 2018, 164, 31-42. [CrossRef]

33. Labra, C.; Rojek, J.; Oñate, E.; Zarate, F. Advances in discrete element modelling of underground excavations. Acta Geotech. 2008, 3, 317-322. [CrossRef]

34. Ming-Gao, C. A study of the behaviour of overlying strata in longwall mining and its application to strata control. In Developments in Geotechnical Engineering; Farmer, I.W., Ed.; Elsevier: Amsterdam, The Netherlands, 1981; Volume 32, pp. 13-17. ISBN 978-0-4444-2086-2.

(C) 2019 by the authors. Licensee MDPI, Basel, Switzerland. This article is an open access article distributed under the terms and conditions of the Creative Commons Attribution (CC BY) license (http://creativecommons.org/licenses/by/4.0/). 